\title{
Drama and Democracy: The Case of Socrates
}

\author{
Barbra GRAZIOSI \\ Durham University
}

Given the topic of this timely conference, what I would like to offer here is an investigation of the trial of Socrates, from three different angles. I start by raising methodological questions about our treatment of the ancient sources, suggesting that we might usefully pay greater attention to the actual charges brought against Socrates in his trial (in as much as we can reconstruct them). Scholars tend to treat the charges of impiety and corruption of the young' as a mere excuse, a cover-up for deeper political resentments against Socrates and his aristocratic pupils. This view effectively offers a 'conspiracy theory' of Socrates' death, suggesting that he was convicted on trumped upcharges that had little to do with the actual reasons for the resentment he inspired. As a methodological experiment, I would actually like to take the charges at face value, and ask how they could sound plausible in court. I conclude, just to give the game away, that the current orthodoxy on the death of Socrates does not pay sufficient attention to what was happening in the streets of Athens - at the level of public, popular performance and display.

In the second part of my paper, I explore what happened after the death of Socrates, thus effectively revisiting our sources for his trial and conviction from a different angle - not now as historical evidence, but rather as literary reception of what was one of the most traumatic events in the history of Athenian democracy. The argument necessarily revolves around Plato, since he offers the most influential version of Socrates' death. I argue that Plato's use of the dialogue form - and of several other dramatic techniques - enhances the impression of polyphony, while actually serving to silence many perspectives on Socrates that were current in Plato's time. By engaging with drama, Plato carves a new (and pointedly antidemocratic) space for philosophy. 


\section{Drama and Democracy: The Case of Socrates}

It is ironic, but also quite fitting, that Plato's dialogues - despite their competitive stance towards drama - have inspired actual theatre. In the third, and final part of my paper, I turn my attention to a play by Ahmed Etman, who is of course one of the heroes of this conference, and of classics more generally. I discuss the English translation of A Belle in the Prison of Socrates published in 2008 (because, to my own loss, I do not read Arabic), but I am aware that the play was re-written over the course of two decades. Etman's Belle engages closely with Plato's work - indeed she is the personification of Demokratia in the Crito. The connections between Athens and Cairo are explored through this central figure and several other means (the play imitates the characters of the back-streets, mentions Plato's trip to Egypt and, as I argue later, injects contemporary themes into ancient history).

This then, is the overall theme of this contribution; now for the details. From a historical point of view, Socrates' death seems a highly unlikely event: Athens was a radical democracy that prided itself on freedom of speech - and all that Socrates did was talk. It is hard to reconstruct quite what charges were brought against him but - on the basis of Xenophon Memorabilia 1.1.1, Plato Apology 24b, and Diogenes Lartius 2.40 - it seems that he was accused of 'not believing in the gods in whom

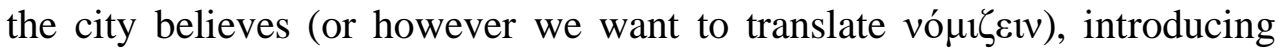
new gods, and corrupting the young'. The jury found him guilty. Technically, however, this may not have led to a death sentence, because Socrates' case fell under the category of 'assessed trials', in which the state acknowledged that there could be different degrees of guilt. The procedure was this: if the defendant was found guilty, the prosecutor would propose a penalty, and the defendant would propose a lesser counter-penalty; then there would a second round of voting. According to Plato, Socrates could have got away with a fine, but he decided to make mockery of the whole procedure - by suggesting, as a penalty, that he should be given free dinners at public expense for the rest of his life. And so the prosecutor's proposal stood: a death sentence. Plato also insists that, even after the verdict, Socrates could have easily escaped from Athens and gone into 


\section{Barbra GRAZIOSI}

exile, but that he chose to abide by the laws of his city (this is most explicitly stated in the Crito). Plato's Socrates was a good Athenian, and would stay in his city and abide by the laws of its democracy, even if it meant death. Thus Plato suggests that Socrates effectively committed suicide.

There is a standard scholarly explanation of the death of Socrates, rehearsed by influential historians and philosophers, such as Alexander

Nehamas in the Oxford Classical Dictionary, and which informs also more popular books, such as Robin Waterfield's Why Socrates Died. Historians usually start from the wider context of Socrates' death. The Athenians had undergone a very difficult period in the thirty years leading up to the trial of Socrates. They had experienced a long and exhausting war against Sparta, which ended in defeat; and a typhoid epidemic that killed at least one quarter of the population. After that, they saw two brutal oligarchic coups: one in 411, the second in 404. They finally managed to restore the democracy in 403/2; and three years proceeded to sentence Socrates to death. Thucydides offered a brilliant analysis of the Peloponnesian War and its moral consequences. About the epidemic, he wrote: 'People no longer strove to be honourable, because they doubted they would live long enough to earn a reputation for honour.' The survivors were, we are asked to imagine, ambitious and unscrupulous. There was Alcibiades, famous for his looks, his horses, his wealth, his drunken excesses, and his on-and-off love affair with Socrates. In the course of the Peloponnesian War, he defected to Sparta and then to Persia; and finally plotted against the democracy in 411. And then there was Critias, one of the thirty tyrants who seized power in 404: he set about 'purging the city', as Lysias, a contemporary witness put it. Hundreds of people were sentenced to death by drinking hemlock, and many more were forced into exile during the rule of the thirty tyrants. Both Alcibiades and Critias were close associates of Socrates; Alcibiades had, as I said, also been his lover for many years. The hypothesis, then, is that Socrates died because he loved and taught the most outrageous aristocrats and violent anti-democrats of his time. 


\section{Drama and Democracy: The Case of Socrates}

It seems probable to me that Socrates' association with the likes of Alcibiades and Critias counted against him in court. This is not just what modern historians suppose; it is a view that circulated in ancient Athens too. The orator Aeschines, for example, in a prosecution speech delivered some fifty years after the death of Socrates, asked the jury: 'Fellow citizens, did you not put to death Socrates the sophist, because it was shown he had been the teacher of Critias, one of the Thirty who overthrew the democracy?' And yet, it seems important to consider the situation in 399 $\mathrm{BC}$ - and not simply draw conclusions based on what people were saying 50 , or 2500 years later. In particular, I want to pay close attention to the charges brought against Socrates. Modern historians have very little time for the gods, and this is understandable. The ancient gods seem to us whatever our modern religious views may be - rather frivolous. To put it bluntly: they do not exist, so charges based on the failure to respect them are likely to weigh little in modern explanations of Socrates' trial. Moral anxiety likewise finds little space in the work of modern historians dealing with the trial of Socrates: it seems less tangible than actual political power (even though every politician knows that moral anxiety deeply affects political processes such as elections). The charge of 'corrupting the young' is thus immediately transformed into a charge of association with, and influence over, specific individuals - Critias and Alcibiades - individuals who wielded (in their time) considerable military and political power. We should do well, however, to remember that Alcibiades had already been killed in 404 BC and Critias in 403 BC. Later in 403 BC a general amnesty prohibited further prosecutions for political offences committed before that date. This amnesty has been used by historians precisely to argue that Socrates was killed because of his friendships with the anti-democrats, but that such friendships could not be brought forward as actual charges. This may be so - but the amnesty was also an expression of the people's will. A decision was made not to persecute people for crimes, or friendships, they had 'committed' in the previous decades. So, just as with the charges, we might do well to pay some attention to the amnesty too - and take it seriously as an expression of democratic decision-making in Athens. 


\section{Barbra GRAZIOSI}

In short, my question is this. Should we put Critias and Alcibiades that is to say, prominent (but dead) generals and politicians - at the heart of our enquiry into the trial of Socrates, or should we start with the ordinary Athenians who actually condemned Socrates to death? The jury consisted of 500 male Athenian citizens drawn by lot. They had no time to consider their verdict: as was the practice then, they heard both prosecution and defense speeches, and then judged immediately.

I wonder whether the good family fathers that found Socrates guilty were really so exclusively concerned with Critias and Alcibiades, and the politics and love affairs of the previous twenty years. Perhaps they felt more threatened by other pupils of Socrates who never led armies or ruled the city - but who were causing much disruption in the streets. The Cynics (literally people who lived like dogs) were visible figures in 399 BC. And their behaviour was outrageous: they masturbated in public, defecated in the streets, were unruly and disorderly in every way, refused to consider themselves citizens, made mockery of the law, and strongly argued against any conventional ideas of the gods. Desmond's excellent book on the Cynics gives a clear picture of their impact. The important thing for my argument is that the Cynics claimed Socrates as their teacher and, indeed, in some respects they were his true heirs. Like him, they practiced their philosophy in the streets. Like him, they sought to make their point by 'public engagement', in the true sense of that phrase. It seems possible to me that the Athenian citizens who found Socrates guilty might have worried that he could turn their sons into dogs; that their decisions were future oriented, in short, rather than an attempt to settle old scores. The moral anxiety, the concern for the gods and the city, which emerge from the charges brought against Socrates, seem to me a fitting (and even likely) response to what the Cynics and other self-declared followers of Socrates were doing in the streets of Athens.

Now, by reminding scholars of the importance of the Cynics - and, indeed, of all those who perform in the streets - I do not mean to say that I have 'solved' the mystery of Socrates' trial. His death remains a challenge, and indeed it always seemed strange, even in his own time. After Socrates 


\section{Drama and Democracy: The Case of Socrates}

was executed, nobody quite knew how this could have happened. Accusers continued to publish prosecution arguments - which unfortunately do not survive. Plato and Xenophon tried hard to defend Socrates from such accusations, which is how we can reconstruct the charges in the first place. Dozens of other people also wrote about Socrates; indeed, hundreds of pamphlets circulated soon after his death, and some of them survive in fragments, quotations and vaguer references. What remains is very helpfully collected by Giannantoni, in a collection runs to four volumes. Reading it makes us see only the tip of the iceberg, but it is a useful exercise none the less - mostly because it helps us to see the context of Plato's own portrait of Socrates. Today, Plato is the highest authority on Socrates but, of course, in his time he first had to establish himself as an authority. He did this in many different ways. As I argue in a different chapter, quoted below, he often alludes to contemporary discourse and, indeed, to the pamphlets that made the case against Socrates. These specific engagements are, however, part of a larger totalizing discourse about Socrates, where the dialogue form plays a central role. Plato gives voice to many different characters, thus creating an impression of polyphony, while in fact carefully controlling the whole messa in scena, the whole staging of a city in dialogue. The characters that appeared in Plato's work were known to his contemporary readers: he could bend them, satirize them, parody them, and turn them into literary figures, but they were and remained in dialogue with perceptions based on real-life encounters, and with representations in other genres and indeed in other Socratic writings. In this sense, Plato was mimetic: he represented dialogues between people who existed in reality, and he parodied the mimetic genres of tragedy and comedy. At the same time, he criticized mimesis as furthest removed from reality. The paradox is well known and, ultimately, concerns above all Plato's relationship to drama, the most mimetic form of art. A lot has been written about this: I have put some few references below, and all I can offer here are some cursory remarks. In what remains (for me at least) the most convincing overall treatment of the issue, Andrea Nightingale argues that Plato draws from the discourse and techniques of drama in order to create a 


\section{Barbra GRAZIOSI}

new (and superior) space for philosophical writing. For example, Plato appropriates the polyphony of Old Comedy, but takes it out of its democratic context. I quote from Andrea Nightingale's book Genres in Dialogue, p. 192:

It was the polyphony that characterized Old Comedy, I would urge, which provided the paradigm for Plato's "mixed" texts. But Plato wrests this formal structure away from its native genre as well as from the privileged position that the genre occupied within the Athenian democracy. Plato's polyphony plays outside the boundaries of the social, political, and cultural transactions of democratic Athens.

Plato's antidemocratic philosophy colours contemporary perceptions of the trial of Socrates. Historians assume that Socrates was killed because he taught the most virulent anti-democrats of his time: Alcibiades, Critias but - of course - also Plato himself. The perception of Socrates, the superior human being, put to death by a misguided and mediocre democracy has stayed with us. Most recently, Etman's play $A$ Belle in the Prison of Socrates, depicts the great philosopher beset and beleaguered on all sides, but especially by the nagging wife. So here there is this supposedly superior intellectual who is, however, surrounded by low-life characters and exchanges.

By association with these comic characters Socrates himself becomes a comic figure in Etman's hands - and philosophy turns, once again, into farce. This is signaled explicitly in the script: in act two, Socrates tries to engage Aristophanes in a philosophical debate, but he is immediately cut short (p. 43):

Aristophanes: Don't you realize, Socrates, that you're in the theatre... you shouldn't start a dialogue with me... for whoever starts a dialogue with you is either and idiot or unfair to himself...

The theatre, then, is not a place for high philosophy - but it is, in Etman's hands (as well as Aristophanes') a place for politics. Reading A Belle in the Prison of Socrates with hindsight, it is not difficult to see in it an echo - or rather an anticipation - of the Egyptian revolution. There is, for example, an indictment of forged democratic elections and military rule. The Chief of Guards says to Socrates, at the very end of the play (p. 99): 


\section{Drama and Democracy: The Case of Socrates}

The former leaders came into office by forging elections... I came into the office by the sword's ege. Which one is better?

Corrupt politicians and generals are good counterparts for the oligarchic Critias and Alcibiades. But what I have tried to argue today is that we should not be seduced into talking about them only. What I have tried to do today is, in effect, to re-consider the trial of Socrates from within the civic space of Athens, and its streets - and this is simultaneously an antiaristocratic and, up-to-a-point, an anti-Platonic reading. Taking for once at face value the charges brought against Socrates, and indeed the political amnesty of $403 \mathrm{BC}$, I have argued that we might consider them to be expressions of democratic decision making, rather than a cover-up for what is effectively construed as a political revenge on dead generals and statesmen. What I would like to suggest, then, is that what happens in the streets (the performances of the Cynics for example, but also the current revolution and its anticipation in Etman's play) has power. Viewed from this perspective, it would seem to me that Socrates was (in ancient Athens) and remains (for example in Cairo today) a useful figure for those who wish to explore how democracy is played out in the open - in the streets and, indeed, on stage.

\section{References:}

Allen, D. 2010, Why Plato Wrote, Malden MA, with Capra's discussion at:

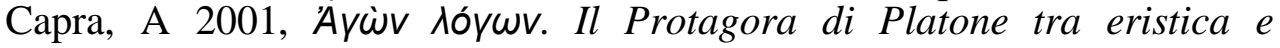
commedia, Milan

Desmond, W. D. 2008, Cynics, Stocksfield

Giannantoni, G. 1990, Socratis et socraticorum reliquiae, 4 volumes, Naples

Graziosi, B. 2009, 'Hesiod in classical Athens: rhapsodes, orators and Platonic discourse' in Plato and

Hesiod, eds. G. Boys-Stones and J. H. Haubold, Oxford

P. Destrée, P. and F.G. Hermann eds. 2011, Plato and the Poets, Leiden

Nightingale, A. W. 1995, Genres in Dialogue: Plato and the Construct of Philosophy, Cambridge

Waterfield, R. 2009, Why Socrates Died: Dispelling the Myths, London 